TITLE:

\title{
A Short History of Table-Talk and Live-Action Role-Playing in Japan: Replays and the Horror Genre as Drivers of Popularity
}

\section{$\operatorname{AUTHOR(S):~}$}

Kamm, Björn-Ole

\section{CITATION:}

Kamm, Björn-Ole. A Short History of Table-Talk and Live-Action Role-Playing in Japan: Replays and the Horror Genre as Drivers of Popularity. Simulation \& Gaming 2019, 50(5): 621-644

ISSUE DATE:

2019-10

URL:

http://hdl.handle.net/2433/266540

\section{RIGHT:}

Björn-Ole Kamm, A Short History of Table-Talk and Live-Action Role-Playing in Japan: Replays and the Horror Genre as Drivers of Popularity, Simulation \& Gaming (Volume 50, Issue 5) pp. 621-644. Copyright @ 2019 The Author. DOl:

10.1177/1046878119879738:; This is not the published version. Please cite only the published version.この論文は出版社 版でありません。引用の際には出版社版をご確認ご利用ください。 


\title{
A Short History of Table-Talk and Live-Action Role-Playing in Japan: Replays and the Horror Genre as Drivers of Popularity
}

\section{Björn-Ole Kamm'}

\begin{abstract}
Background. The history of larp, live-action role-play, in Japan may be rather short but documents exponential growth in the entertainment sector as well as in educational gaming. Following trends of related forms of analog role-playing games, the horror genre functions as a motor of increasing popularity.

Aim. This article explores the development of non-digital role-playing games in the Japanese context in light of the online video platform niconico popularizing horror role-playing and practical considerations of adopting the genre to liveaction play.

Method. Cyberethnographic fieldwork including participant observation at larps between 2015 and 2018 forms the data basis for this article, followed by qualitative interviews with larp organizers, larp writers, and designers of analog games as well as observations online in respective webforums.

Results. Replays, novelized transcripts of play sessions, have been an entry point into analog role-playing in Japan since the 1980 s. With the advent of video sharing sites, replays moved from the book to audio-visual records and a focus on horror games. Creating a fertile ground for this genre, the first indigenous Japanese larp rulebook built on this interest and the ease of access, namely that players do not need elaborate costumes or equipment to participate in modern horror.
\end{abstract}

'Kyoto University, Japan

\section{Corresponding Author:}

Björn-Ole Kamm, Senior Lecturer, Transcultural Studies, Graduate School of Letters, Kyoto University, Kyoto 606-850I, Japan.

Email: kamm.bjornole.7e@kyoto-u.ac.jp 
Discussion. The dominant form of larps in Japan are one-room games, that work well with horror mysteries and function as a low threshold of accessibility. Furthermore, the emotional impact of horror larps, the affective interaction between players and their characters, allows for memorable experiences and so continues to draw in new players and organizers.

\section{Keywords}

analog role-playing game, cyberethnography, horror, Japan, larp, replay

\section{Introduction}

Digital games from originally Japanese - now multinational - companies have become a stable feature of entertainment worldwide since Nintendo and others filled the void left after the US gaming industry crashed in the 1980s (O'Donnell, 2012). Especially, console role-playing games (RPGs) such as Dragon Quest (Horii, 1986) or Final Fantasy (Sakaguchi, 1987) have become global household names that developed into multi-media franchises and built the groundwork for game mechanics at the core of many RPGs until today (Consalvo, 2016).

Contrastingly, the world of non-digital games in and from Japan often remains unacknowledged or is much less known outside of Japan. Only the translation work of a number of cultural brokers gave some Japanese-language games a wider exposure (Kamm, 2017). These games belong to the type called tabletop or pen \& paper roleplaying, of which the US game Dungeons \& Dragons (or D\&D; Gygax \& Arneson, 1974) is recognized as the first advertised as such and kickstarting the industry (Peterson, 2012). D\&D would also influence many later developments, such as the mainstream of live-action role-play (larp). The industry in Japan took at times different routes than in the US or Europe and currently experiences its second boom, with much attention on the horror genre and larp. Since 2015, larp sees exponential growth rates in player numbers and publishers rush to cover territory in this field. This occurs at a time when also scholars increasingly venture into this field to understand the various practices called role-playing games and potentially use fantasy gaming for learning (cf. Hammer, To, Schrier, Bowman, \& Kaufman, 2018; Katō, Fujino, Itoi, \& Yoneda, 2012). Many attempt to bring insights from previous scholarship, such as Gary Alan Fine's seminal Shared Fantasy: Role-Playing Games as Social Worlds (1983), up to date in relation to current developments (e.g., Bowman, 2010). Landmark publications, such as Role-Playing Game Studies: Transmedia Foundations (Zagal \& Deterding, 2018), cover much necessary ground, however, retain a focus on practices and experiences in the US and European contexts.

Thus, this paper seeks to fill a gap concerning the history of non-digital RPGs in Japan to understand the place of new forms such as larp in the Japanese context and their relationship to trends such as the popularity of the horror genre. Keys to exploring this development are so-called replays, a form of literature that emerged out of RPG practices particular to Japan, and the online video platform niconico, where 
role-players distribute videos of their game sessions. The research behind this paper followed a cyberethnographic approach that takes offline and online situations and interactions into account. With the current popularity of horror RPGs, the exploration also allows for an examination of how larpers in Japan have adapted the practice to their environment, including one-room set-ups that offer themselves for horror and mystery settings. The main aim of this paper is to situate analog RPGs in their Japanese context. Still, the discussion of practical aspects may offer ideas for other forms of gaming and simulation that deal with emotions.

\section{The Family of Role-Playing Games}

The aforementioned D\&D found its way to Japan in the early 1980s, roughly the same time its digital cousin Wizardry (Greenberg \& Woodhead, 1981) entered the Japanese market and inspired Sakaguchi to develop Final Fantasy. Computer mediated roleplaying games found an audience much quicker than their non-digital predecessors (Okawada, 2017). Videogames can be played alone. Contrastingly, games like D\&D need a minimum number of players to come together, necessitate the familiarization with complex rules, and make the leap from reading the rulebooks to actual play rather difficult for newcomers. This characteristic spawned a new form of literature, socalled replays, to which we will return in more detail below. Unsurprisingly, these games never reached the same exposure as their computer cousins, so that the acronym RPG in the Japanese context is very much limited to digital gaming. To distinguish the analog variant, Japanese game designers coined the term table-talk role-playing game or TRPG (Kondō, 1987). The least common denominator of most forms of RPGs can be reduced to players controlling so-called characters in a pre-defined setting or world to create a shared story during which those characters grow in capabilities (Hitchens \& Drachen, 2009; Montola, 2003). Game worlds can range from Lord of the Rings inspired settings to simulacra of our everyday. Characters resemble a mix of settingrelevant traits, such as a fictitious personal history and motivations, and game-play relevant traits. Such character abilities or skills are represented by numbers, for example, dexterity 3 on a 5-point scale. TRPGs (and many larps) represent these characters on elaborate character sheets (see Figure 1). Some computer RPGs directly recreate TRPG settings and mechanics into a digital game engine, for example the Baldur's Gate series (Ohlen, 1998), replacing the human game master (rules referee and plot writer) with a computer.

Recently, another cousin of these analog and digital games increasingly gains popularity worldwide and also in Japan: Larp. Faithful to its name, during TRPG sessions the players sit around a table talking. One player functions as referee (called game master, storyteller, or keeper) and they all verbally describe what their characters are doing. Then they throw dice and calculate the results based on skill and ability levels in order to see if the characters succeed at their chosen actions. In a larp, players often dress-up as their characters, walk around the play area - which can be a single room or several hectares of a pseudo-medieval tent city - and interact with each other in an improv-theatre-like manner to overcome challenges and create shared stories. Similar 


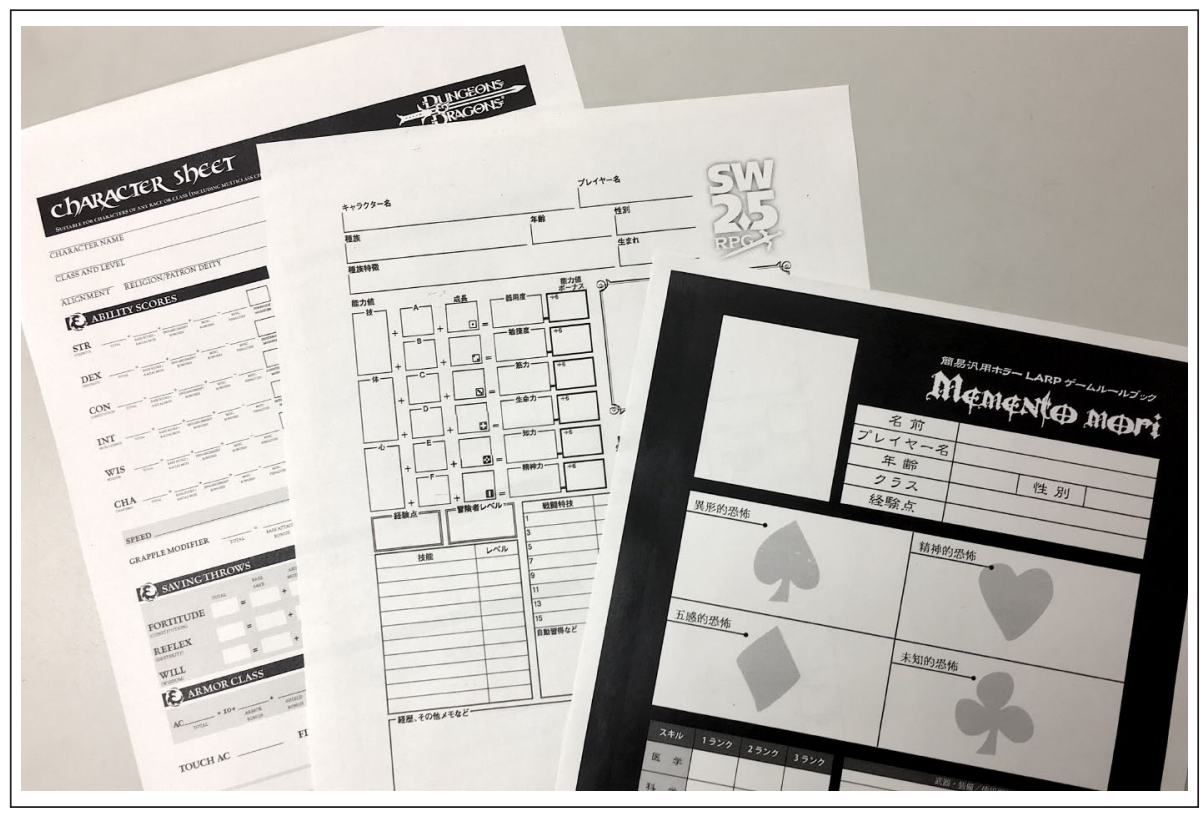

Figure I. Character sheet examples from D\&D 3.5 edition (Gygax, Arneson, Tweet, Cook, \& Williams, 2003), Sword World 2.5 edition (Kitazawa \& GroupSNE, 2018) and the larp Memento Mori (Hoshikuzu \& CLOSS, 2015).

to TRPGs and computer RPGs, the mainstream of larps is best understood as a form of entertainment - a para-telic activity done for its own sake (Apter, 1991) - and belongs to the fantasy and science-fiction genres. Larps and TRPGs also venture into areas that go beyond having fun: For example, by playing nobles and their servants in a larp set in late 19th century England, players may directly experience the class conflicts of this era to discuss these experiences after play (Fairweather Manor, Dziobak, 2015). By playing a fantasy TRPG, children diagnosed with Autism Spectrum Disorder may learn to reach consensus within the game but also to communicate better with friends and family outside the game (Katō, Fujino, \& Yoneda, 2013).

Analog RPGs may not be as successful economically as their digital cousins. In the US and Canada, role-playing games show a growth in recent years but are still a tiny market with approx. \$35 million of annual sales compared to $\$ 625$ million of collectible games, such as trading cards, or $\$ 91$ billion of video games (Griepp, 2016). Giving a number from Japan, D\&D translations by Hobby Japan have a print run of only 6.000 copies because the publisher knows that this amount will be sold to its existing customer base without running much risk (replay sales are much higher, see below). The impact of analog role-playing games, especially those made in Japan, hails from their close interlinking with other media. Beginning with the Record of Lodoss War franchise, many popular manga and anime have their roots in TRPGs. In the opposite direction, most fantasy and science-fiction franchises, from Game of Thrones to Star 
Trek and The Walking Dead have their TRPG variant. In Europe, thousands of players participate in week-long fantasy larps each summer. Parents increasingly delight in their children larping because they play outside instead of in front of smartphone and computer screens. Thus, they send their children to youth larps or bring them along to events in which the parents themselves participate. In Japan, tourism agencies increasingly take note of what experiences larp could offer to draw more visitors to local areas. A 2019 ninja larp campaign in Iga-city is the most recent example.

Coming out of the US-American wargaming hobby, D\&D and its successors can be traced back to 19th century conflict simulations (Appelcline, 2014; Peterson, 2012). Contrastingly, larp is hard to link back to a definite "origin," so that scholars speak of "multiple sources" (Harviainen, 2012, p. 18) or "patterns of sporadic emergence" (Stenros \& Montola, 2011), highlighting how different people at different locations independently came up with the idea of dressing-up as their characters and enacting their adventures. Larp historians identify only in hindsight similarities to gladiatorial fights in Ancient Rome, the Italian Commedia dell'arte theater, or the Society for Creative Anachronism and other sibling practices (Morton, 2007). Larpers will borrow techniques from Method Acting or Moreno's psychodrama (Moreno, 1987), but larp did not evolve out of these practices. Thus, larp history can only be a story of family resemblance (Wittgenstein, 1953/2009, p. 36e): We cannot identify direct connections or a succession of development but shared attributes and characteristics instead, none of which are necessary. I understand terms like "larp" - and by extension all forms of role-playing games - not as concepts but as hyperlinks: They bring practices into relation and so create awareness. With each event being an individual experience by its players, it is this awareness of doing larp that connects these experiences rather than an abstract definition (Kamm, 2019, in press).

\section{Categories and Rules of Playing}

Linking back to their roots in wargaming and conflict simulation, TRPG rules may be extremely simulationist. For example, when a character shoots an arrow, players will have to consult various tables to judge where the arrow went: What are the wind conditions? How far away is the target? Does the target wear armor?

The term simulationist derives from a model for RPG design developed by Ron Edwards in discussions with other independent game designers on the rgfa usenet group and The Forge website (thus, later named Forge Theory). The so-called GNS model recognizes three creative player agendas as basis for in-game decision making, Gamist (competition between players), Narrativist (shared storytelling via role-playing), and Simulationist (internal logic and experiential consistency), of which designers should be aware when creating RPGs (cf. Young, 2003). Larp theory exchanges simulationist with immersionist to highlight how players seek to fully think like their characters as basis for decisions (Bøckman, 2003). Such categories saw hot discussions, especially because they may be used to stereotype playstyles negatively. However, as a tool for game design and a way to advertise games (comparable to genres), they stuck and have been received worldwide, also in Japan (as GNS-riron). 
If we borrow from this model, then many Japanese-language games developed since the 1990s follow a narrativist approach because their focus is on storytelling, less on simulating fantasy battles. Actions are resolved in line with the question if they fit the story or theme. In a competitive or simulationist game, it's the players' loss if they do not hit the target. In a story focused game, this can turn into a dramatic scene enriching the narrative. Some Japanese games do not even use dice but rather trump cards and resource management - players save powerful cards for superhuman feats in the climatic confrontation with their adversary. Japanese-language games centering on this narrative-based play-style often favor contained stories that can be played in one sitting instead of long campaigns. Taking limited resources of time and space into account, game developers went into this direction to revive the TRPG market in the 1990 s when player numbers dwindled. ${ }^{1}$ Regardless of what game designers have in mind, however, the agency is with the players: They can play with a simulationist rulesystem but never touch any dice; or they can just play a series of battles with a storyfocused ruleset.

Because larps do not need much simulation there are fewer rules: Instead of throwing dice players actually fight each other using soft boffer weapons. If we look at the large fantasy larps in Germany, for example ConQuest of Mythodea (Live Adventure, since 2004), then the basic set-up resembles very much D\&D-like TRPGs: A fantasy world like Lord of the Rings' MiddleEarth with elves, wizards, and knights who seek treasure and fame by battling orcs, undead, and each other. However, instead of one GM and a couple of players, over a thousand staff members handle plots, rules, and also sanitary needs of over 8.500 participants for about five days. Plot-hunters will more or less do what a TRPG troupe does: Learn as much as possible about the world, find quests, defeat enemies, and gain glory in the large battles during the event. Other players will focus on immersing themselves in their characters, how they live and think, staying within their camp, cooking hobbit food or working as a blacksmith. Costuming and equipment - the aforementioned weaponry - become very important elements compared to TRPGs. This fact has spawned a whole industry where larpers can buy any form of armor, clothes, and weapons to match or even surpass their role models of Hollywood cinema.

Smaller fantasy larps, with 15-200 participants, more or less mirror their big cousins. One most important, shared aspect of all larps, however, has not much to do with rules, costumes, or scale - an aspect that has profound influence on researching larp: Larps cannot be summarized. Each participant experiences something different, from the point of view of their character. There may be larger plot events during a larp - a speech by an evil lord, the attack on the elven village - but if a player was not there, this does not become part of their experience. If we take the metaphor that a TRPG troupe resembles the main cast of a movie, then we would have about eight thousand movies of a larp like ConQuest.

In 2011, it appeared as if "Japan did not larp" (Kamm, 2011) - an observation quite based in a limited understanding of larp. However, it is more correct to say that there was no awareness for larp. Very similar practices did exist but were not named larp. Three obvious examples are cosplay, airsoft ("survival games" in Japanese), and 
escape rooms. Developed under the (brand) name "Real Escape Game" (riāru dasshutsu gēmu) by the Kyoto company SCRAP in 2007, the latter soon spread worldwide. Players need to solve puzzles to get out of a room, which can be set-up as anything, from a dungeon to an airplane. Similar to airsoft - a competitive team sport where players use air weapon replica to shoot each other - escape rooms do not ask for role-playing, people participate as themselves. However, players are free to create characters and play these games and so could name them larps. Cosplay - a neologism combining costume and play - refers to dressing-up as characters from movies, comics, or games, and has its origins in the US-American Worldcon and Japanese ScienceFiction Convention (where participants for the first time dressed as anime and manga characters; Ogonoski, 2014; Winge, 2006). The main difference to role-playing in the Japanese context is the motivation: As the game designer of Ryūtama, Okada Atsuhiro, who has cosplay experience, told me in an interview, role-players want to play a (selfdesigned) character in a newly unfolding story. Contrastingly, cosplayers seek to recreate the outlook and signature poses of existing characters from anime, games, and movies for taking photos. Based on interviews with respective magazine editors, game designers, and players, the populations of these practices do seldom overlap. However, the boundaries between these practices increasingly blur, e.g. larpers in Japan buy costume parts in cosplay shops. Thus, larp has and continues to change with Japanese players reassembling and adjusting the practice to their needs (Kamm, 2019). They borrow from and integrate other cultural practices, one example of which are horror movies as discussed below. ${ }^{2}$

\section{Methodology}

Studying the various practices and games of role-playing in Japan necessitated an approach that focused on gaining new information about a hitherto barely researched topic. Furthermore, as comprehensive lists of role-players do not exist, a random sample for a quantitative study could not be drawn. Thus, a qualitative, data-generating methodology including participant observations and interviews was chosen.

In light of the ubiquitous use of smart phones and other Internet devices, cyberethnography builds on the insight that the separation in a virtual, not-real space and a real world does not mirror human experience (cf., Hine, 2008). The perspective understands cyberspace as contexts mediated by computer technology but also inseparably linked to supposed-to-be real sites (Teli, Pisanu, \& Hakken, 2007). Internet technologies and the communication they enable became not only a site or subject of investigation but also an important tool for my research. For example, I recruited most of my interviewees by posting on respective online group forums, for example the TRPG group on mixi.jp (a Facebook-like SNS, now surpassed by Twitter). One such interviewee, a professional illustrator of TRPG game books, later introduced me to Bouken, one of the first TRPG publishers of Japan. Between 2010 and 2014, I interviewed over 25 male and female non- and semi-professional role-players between the ages of 18 and 55, including residents of Tokyo, Saitama, Aichi, Shizuoka, and Hokkaido. After returning from my fieldwork in Japan, I was able to conduct observations at the 
international game fair SPIEL at the booth of Bouken. Thus, my research of a Japanese game studio was not limited to investigations in Japan alone. People I met online first, I also spoke to offline, and role-players I met offline connected with me also online.

I also aimed at gaining insight into production and design. Through my first contacts, I was able to talk to business members about RPG history, including independent designers but mostly illustrators and game designers working for the game studios F.E.A.R. (Tokyo), GroupSNE (Osaka/Kobe), and Bouken mentioned above. With most of my informants, laymen as well as professionals, I stayed in contact months and years after the initial interview, in some cases until today.

Since 2015, the focus of the fieldwork moved to larp, with participant observations at larp groups and events in Tokyo, Saitama, Aichi, and Mie. I conducted formal and fieldwork interviews with larpers and semi-professional larp designers as well as investigations on Twitter, the most used medium for communication today. In addition, I investigated RPG play transcripts uploaded to the online video platform niconico.

I augmented my fieldwork and interviews with the analysis of respective Japanese publications related to role-playing games, such as issues from the original run of the Japanese-language magazine Warlock or its more recent, new edition, ${ }^{3}$ as well as guidebooks published by larp groups, and their rulebooks.

\section{Findings I: TRPGs and Horror}

TRPGs in the form of D\&D were introduced to Japan by science-fiction author and later founder of GroupSNE, Yasuda Hitoshi, and his fellow students at Kyoto University in the early 1980s. Over 30 years later, larps - or better, an awareness for larp - came to Japan via an abridged and translated version of the popular German larp rulebook DragonSys (Schlump \& Hölzel, 2004). Both forms of role-playing game soon developed in their own directions, re-assembling the practice in particular globallocal ways. Key aspects of the developments were the literary type replay, its video variant, and the horror genre, which will be used as guides through the historical development sketched below.

\section{Replays}

Yasuda Hitoshi and his companions from the Kyoto University Science-Fiction Club ${ }^{4}$ - including novelists Yamamoto Hiroshi and Mizuno Ryō - encountered D\&D advertisements in the US American magazine Fantasy and Science Fiction. They soon ordered copies of the game and also went to the US Science Fiction Convention to learn about it (Okawada, 2017; R. Yasuda, 2016). While the D\&D Basic Set came with a prewritten scenario, other games, such as Traveller (first edition, Miller, Chadwick, et al., 1977), did not, which made it hard to play for new players. ${ }^{5}$

Thus, they sought to introduce new players by publishing transcripts of their own play sessions: The replay form was born. In 1986, the group published the first part of their D\&D Record of Lodoss War Replay in the computer game magazine Comptiq $(\mathrm{H}$. Yasuda \& GroupSNE, 1986), the same year they also incorporated as GroupSNE, 
Japan's first TRPG design studio. Record of Lodoss War was later turned into a novel series by Mizuno and published by Kadokawa. Nagaoka Akinori directed an anime series, on which several manga also released by Kadokawa as well as several PC and console games followed. The setting of these stories became the game world for GroupSNE's own TRPG Sword World RPG and the Record of Lodoss War Companion rulebook in 1989. ${ }^{6}$ Sword World - now in its 2.5th edition - became the gold standard of TRPGs throughout the 1990s. The original replay not only introduced a whole generation to a new form of play but also opened a market particular to Japan.

Replays fall into the category of so-called light novels usually targeted at young adults. Light novels exist since the 1970s, were a spring board for many successful authors, and experienced a slight boom in the early 2000s (Ichiyanagi \& Kume, 2009, p. 290). Light novels are usually about 50,000 words long, come with manga-style illustrations on the cover, and are published in paperback format (tankōbon). Bestseller series reach numbers of 30 million sold copies. As described above for Record of Lodoss War, a successful series soon finds adaptation as manga, anime, game, and/or live action movie. A close, continuous link exists with TRPGs (Nakamura, 2009, p. 104), for example, when we see that manuals for aspiring authors suggest to use TRPG character creation steps for setting up characters for a novel (Ōtsuka, 2003).

A replay is a novelized transcript of actually played game sessions - at least, publishers and studios claim so when asked at conventions. The structure follows how TRPGs are played, that is, in the form of a conversation between GM and players intersected with dice rolling. In a replay, the latter is either made part of the main text or can be found in footnotes, sometimes accompanied by longer rules explanations (see example below).

GM: So both of you traveled through the grasslands without any troubles. However, along the way you find that the road has washed away! Roll the Direction Check to see if you lose the way to your destination. Who's the Mapper?

Haruka: That's me! Just in case, I'll be casting my beginner's magic "Acorn Compass." The magic Incantation Check. . . (rolls) worked so I rolled an 8, a success!

GM: Ok, an arrow-shaped object is conjured by Haruka's magic, and points out the way to the destination as you walk!

Haruka: Alright, let's follow Mr. Arrow ! (laughs) (Excerpt from the English edition of Ryūtama; Okada, 2015, pp. 88-89; original Japanese edition, 2007).

All major game studios and publishers, GroupSNE, Bouken, and Hobby Japan since the 1980s, F.E.A.R. and Arclight since the 1990s, as well as independent designers deliver replays in addition to their TRPGs or publish their games in the form of replays accompanied by the rules in an appendix. New players can thus learn how the game designers envisioned their product to be played. Based on interviews with these game studios, replays are one of their biggest revenue sources in the TRPG segment. Outside Japan, publishers could only dream of such a steady revenue stream (Winkler, 2006). Here, we also encounter novels and other media either based on play sessions of the 
game designers or taking place in role-playing game worlds. The most famous are the Dragonlance series by Margaret Weis and Tracy Hickman and R.A. Salvatore's Drizzt Do'Urden novels playing in the Forgotten Realms setting. Such novels, however, do not feature the transcript-like format of Japanese replays.

Analysis of self-introductory threads in the TRPG group on the SNS mixi.jp between 2005 and 2012 revealed that over $40 \%$ of role-players introducing themselves there came to the practice via replays and that over $70 \%$ enjoyed reading them still. Roughly $20 \%$ mentioned that they had never played and only read the replays. Only 15 , less than $2 \%$, had watched replay videos, which increasingly became available with the video sharing platform niconico since 2008. From 2012 onwards, the number of people becoming aware of TRPGs via videos grew in number rapidly.

\section{Niconico}

Replays by amateurs had been a stable feature of conventions and trade fairs where role-players could sell their own independently developed games or fan art as well as replays of their favorite games. Niconico now allowed these amateurs and semi-professionals to distribute video recordings of their game sessions.

Launched in 2006 by Dwango Inc. to first stream Youtube videos and offer users a service to comment on those videos, niconico (then named Nico Nico Dōga, "smiling movies") started to host user videos itself in 2007 after Youtube cut access due to too heavy traffic. While watching, users can comment on a video and interact with the uploader in a fashion similar to chatting. Next to advertisements, much of niconico's revenue comes from their ca. two million premium users and their affiliate program. ${ }^{7}$ Today, niconico is also available in English and Chinese. Besides its commenting system, niconico integrates a huge Wikipedia-like collection of entries named Nicopedia, where technical terms pertaining the website itself but also its categories, such as TRPG, are explained and interlinked with the video content.

Professionally and independently published replays necessitate the transcription of several hours of play, the layout and distribution of the work. On niconico all this can be reduced to simply uploading an audio recording and an image file. Soon, however, groups learned that to gather attention, their videos needed more: Today, video replays include drawings if not animations and visual displays of game rules and explanations to draw-in viewers (see Figure 2).

To a limited degree, the replay videos bear some resemblance to the US web series Critical Role where professional voice actors (mostly working in animation and gaming) have been live streaming their D\&D campaigns since $2015 .{ }^{8}$ Another similar format is HarmonQuest, run by television producer Dan Harmon, which intersects live TV scenes of the players with animated scenes of their characters (two seasons, 2016 streamed on Seeso, since 2017 on VRV). With its 25 minutes per episode, HarmonQuest speaks to a broader audience than Critical Role, which covers a complete game session of 3 to 6 hours each episode like niconico replay videos would do. Interrupted only by adverts for the $D \& D$ Beyond toolset or their own subscription service, visually Critical Role mainly features frontal views of the game master, Matthew Mercer, and his 


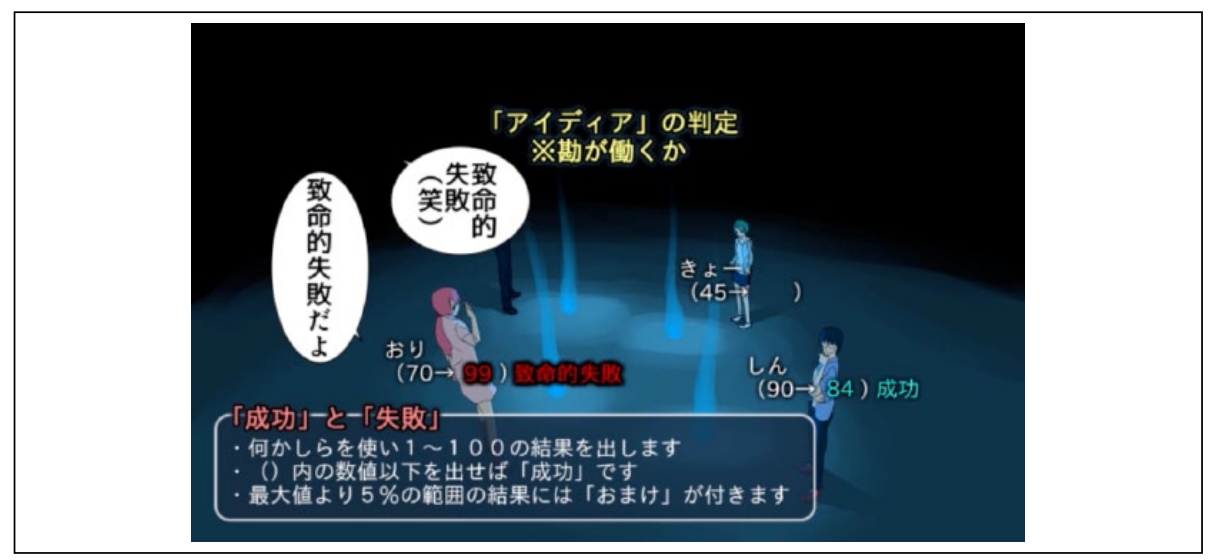

Figure 2. Screenshot from "Actually really fun Cthulhu Mythos TRPG” ("Jitsu ha meccha omoshiroi kuturufu shinwa TRPG," 2015), explaining how dice checks work, e.g. that a result of 99 is a fumble.

companion voice actors. Worth mentioning is that replay books by professional studios in Japan also often involve the casting of popular animation voice actors who then appear during product launches, too. Videos on niconico on the other hand are produced mostly by amateurs who never show their faces in the videos but rely on simple animations or drawings like in the screenshot above. With the exception of videos with known voice actors, few producers use their real voices (see voiceroids below).

Out of a bit over 16 million videos hosted on niconico, over 40,000 videos are tagged with "TRPG" under the category "Anime - Art - Games." A top-rated video on the platform can have millions of views and thousands of comments. The most viewed video in the TRPG area - from which the above screenshot originates - has over four million views and gives an introduction to the Call of Cthulhu role-playing game. As of August 2019, the majority of TRPG replay videos actually deals with this game: More than 35,000 videos fall into a category associated with the Cthulhu Mythos, the fictional universe based on the writings of horror author H.P. Lovecraft. His "The Call of Cthulhu" (1928) especially deals with the cosmic, evil entity Cthulhu, a colossal humanoid with dragon wings and an octopus-head. ${ }^{9}$ How has this "Great Old One" triumphed over all other TRPG genres?

\section{Horror and Role-Playing}

In 1981, the board and role-playing game publisher Chaosium released the first TRPG based on Lovecraft's work (Petersen \& Willis, 1981), in which players would take on the role of rather ordinary people, such as students, archeologists, novelists, or private detectives. During play, they would encounter demonic scriptures and unexplainable phenomena and fight for their sanity - or better, run away. A major theme of Lovecraftian horror revolves around knowledge about a "true reality," knowledge that 
would destroy the feeble minds of humans. The first Japanese translation of Call of Cthulhu (CoC), Kuturufu no yobigoe, appeared in 1986, based on the 2nd edition of the game, with a basic setting of the 1920s, Lovecraft's most productive years (Petersen $\&$ Willis, 1986). Later, 1890s and "present day" settings were added and supported with game material, such as pre-written scenarios. Currently, $\mathrm{CoC}$ is in its seventh edition in English (Petersen, Willis, Mason, \& Fricker, 2016). The most recent Japanese translation - Kuturufu shinwa TRPG (Petersen \& Willis, 2004) - is based on the sixth edition but supported with a number of Japan-only releases, such as Kuturufu to teikoku (Cthulhu and Empire, set in 1920-30s Japan; Sakamoto \& Bandō, 2005), Kuturufu 2010 (Sakamoto, Uchiyama, \& Bandō, 2010) and Kuturufu 2015 (Sakamoto, Uchiyama, \& Bandō, 2015), which supply a modern Japanese setting. ${ }^{10}$

$\mathrm{CoC}$ was one of the first major departures from the fantasy, sword-and-sorcery genre established by D\&D and its cousins, Sword World RPG for example. In 1991 White Wolf Publishing's Vampire: The Masquerade (Rein Hagen, 1991) would further depart by placing the players not in the role of heroes but in the role of the monsters themselves. In Japan, CoC has replaced D\&D and also most locally designed games - of which there are plenty - as the most well-known TRPG. When the description of TRPG in the 2010 convention catalogue of the bi-annual, Tokyo Comic Market listed D\&D and Sword World as examples, the 2016 catalogue reads "Table-talk RPG (Call of Cthulhu etc.)" (see Figure 3).

At the market itself, most contributions - scenario books, replays, fan art - also deal with Cthulhu or are linked to $\mathrm{CoC}$. Few of my interviewees, professionals or amateurs, could offer ideas to why this horror game has gained such a popularity and currently works as a major recruiter into role-playing games. However, most agree on 2012 being the turning point, a year when interest in $\mathrm{CoC}$ peaked for the first time. Looking at niconico, there were popular $\mathrm{CoC}$ replay videos before 2012, most notably the Yukkuri-tachi no Kuturufu no yobigoe series (from March 2011), ${ }^{11}$ which uses speech synthesizer technology to deliver the conversation between the keeper (GM) and the players. Speech or voice synthesizing gained some attention recently due to so-called vocaloids, voice archetypes/libraries for singing (cf. Bell, 2016). Softalk's Yukkuri or the various AH-Software voiceroids are similar programs for speech, where text-input is synthesized, and the user can adjust tempo, pitch, and intonation for more natural results. Used for TRPG replays, such software gained novelty attention but was not limited to CoC.

One informant pointed me to a popular anime television show that was released in early 2012 and which may have spawned an increased interest in the Cthulhu Mythos, subsequently drawing people to TRPG replay videos on niconico and thus to roleplaying: Haiyore! Nyaruko-san ("Nyaruko: Crawling with Love"). ${ }^{12}$ The title character, Nyaruko-san, is the Crawling Chaos Nyarlathotep, one of the Great Old Ones of Lovecraft's Cthulhu Mythos. In the novel and anime, the character may be a shapeless entity but appears usually as a silver-haired girl. Sent by the Space Defense Agency to Earth, she rescues a school boy named Yasaka Mahiro from an alien kidnapper. She falls in love with him and together with other Lovecraftian horrors protects him and Earth from various other monsters. The series does not go beyond any other boy-loves/ 


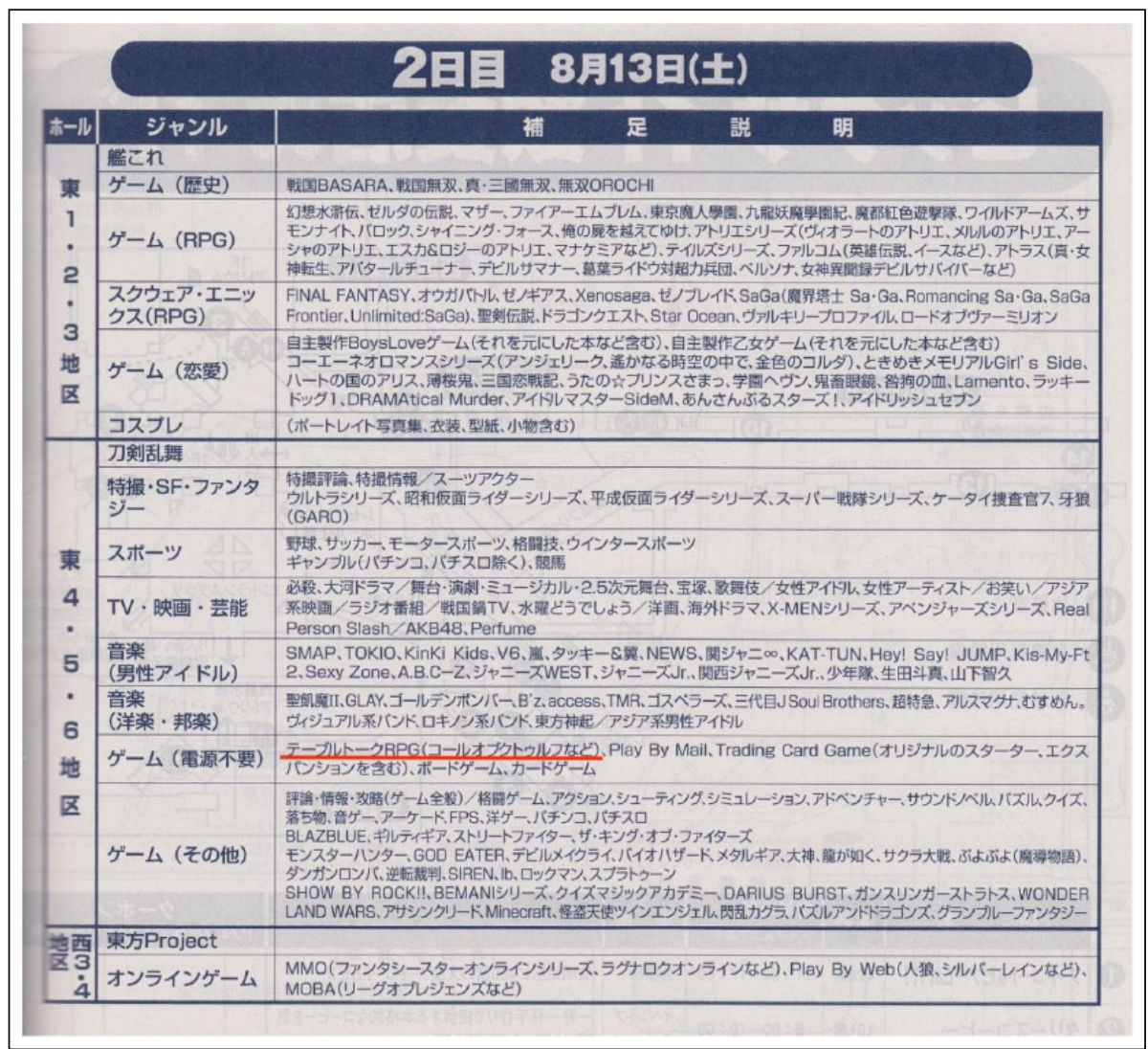

Figure3. Comic Market 90 Catalogue (Comiket, 2016, 55).

loves-not-cute-alien story we find in many anime and often appears like a parody of itself. However, it stands out in its high-level inter-textuality, referencing many other series and also the CoC role-playing game, especially one popular replay, $R$ 'lyeh Antique (Uchiyama, 2009). ${ }^{13}$ With feature and smart phones always at the ready, such references invite viewers not familiar with these texts to search for them online, leading them to Wiki- and Nicopedia as well as replay videos of CoC. Availability breeds interest and interest demands more availability as uploaders realize what genres draw viewer attention, so that currently the output of and demand for $\mathrm{CoC}$ replay videos is continuing. ${ }^{14}$

Within this horror and Cthulhu enriched context of role-playing, the first Japanese larp rulebook sees publication: Memento Mori, a universal horror larp rule-system(Hoshikuzu $\&$ CLOSS, 2015). The authors, however, did not just ride a current trend, horror larp offers practical advantages to new players and larp organizers, most importantly a low threshold when it comes to locations and equipment (Hinasaki, 2019, 136-137). 


\section{Findings II: Larp Styles}

As mentioned above, a number of practices - live RPG, cosplay, escape games, airsoft ${ }^{15}$ - appear as siblings to larp, and depending on how people engage in their actualization (e.g., by creating characters and role-playing them in an escape room or during an airsoft competition), could be labelled larp. Before 2011, however, there existed not much of an awareness of larp in Japan, or if there was, larp was deemed not possible to be actualized (Kamm, 2011). My role-player informants did not see a space for this practice and could not create a "link" to larp elsewhere. "Space" here refers to material space: Having seen Youtube videos about larps in Europe, many said there were no equivalent castles available in Japan. Even more so it means societal space because they feared the same ridicule and ostracism, for example, cosplayers face in Japan. ${ }^{16}$

A change occurred between 2011 and 2013, when first the medieval fighting school Tintagel in Mejiro, Tokyo, offered larp workshops and a larp campaign. They soon stopped the program, only so that two participants would start their own group, Laymūn larp, in Saitama prefecture (Kamm, 2019). Laymūn used the fantasy larp rules Patoria Sōlis (Stahlberg \& Sugiura, 2012), an abridged and adjusted Japanese and English translation of the German rule system DragonSys (Schlump \& Hölzel, 2004), and set their monthly games in the world of Sworld World RPG. Publishing various guidebooks on costumes, equipment or larp organization (Hinasaki, 2013, 2015), the group soon placed much emphasis on spreading the word. They held workshops in various locations throughout Japan and founded a national larp association, CLOSS, to separate these consulting and public relations activities from their game organization as Laymūn. From barely a dozen players in 2012 the practice has spread to several hundred, self-identified larpers organized in ten groups or circles within only six years (CLOSS, 2018). Publishers and established game studios follow this trend, with GroupSNE, for example, now distributing a larp ruleset for their Sword World franchise. ${ }^{17}$ Fantasy and sword-and-sorcery genres show a strong growth, however, for many horror was their point of entry. The first Japanese-language larp rulebook dealt with this genre as well, building on the strengths of the Laymūn style of larping.

\section{Practical Particularities}

All larps are particular actualizations, combining more-or-less global aspects, such as the use of characters, interactively with local materials and styles. Laymūn style larp is characterized by a one-room set-up and a guided, narrative structure. Contrastingly, outdoor fantasy larp in Europe rather works with locations: Players journey to a specific location, where a GM and several non-player characters (NPCs, such as adversaries or helpers) pose a threat or a riddle, and move on to another location once they overcome the challenge. Because Laymūn organizes their larps indoors, using a single room in a community center, the play is structured into scenes. A GM announces a scene, describes the set-up, and the players follow these instructions in their 


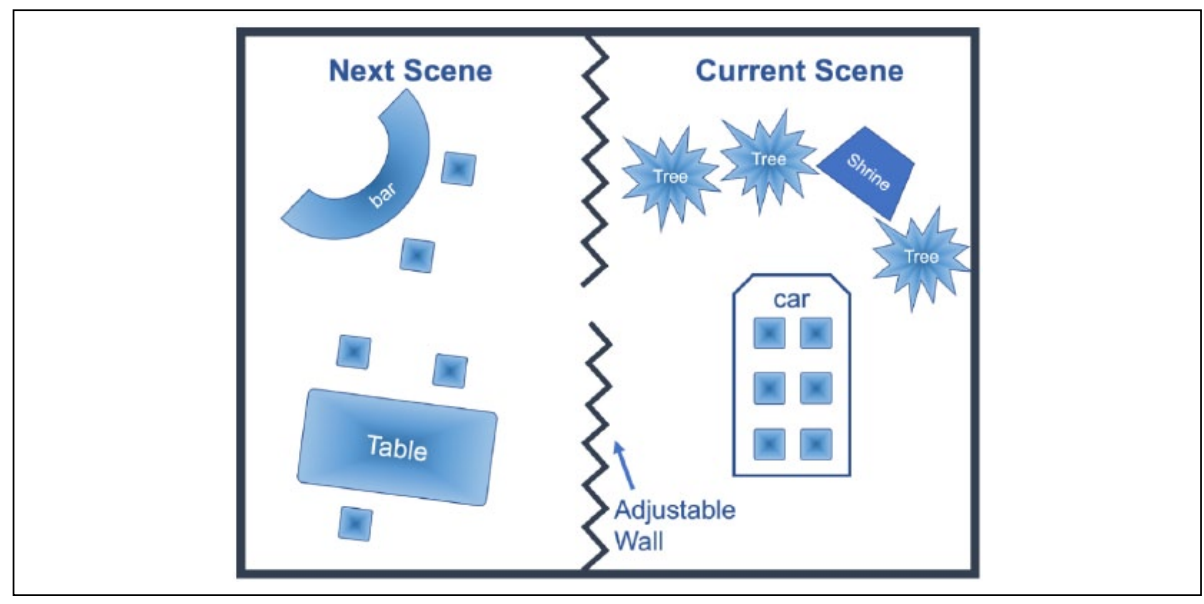

Figure4. Example of a room set-up (illustration by the author).

improvised play. The room Laymūn uses can be divided with an adjustable wall, so that some form of movement can be played out. For example, players learn of a clue in Scene 1 and can decide where they go next. Meanwhile, the organizers prepare the other half of the room for the next scene (see Figure 4).

TRPGs only saw market growth again once designers tailored them to the Japanese context: A quick, narrative-oriented play-style that takes into account the limited freetime of (adult) players. Similarly, Laymūn favor game sessions that are played in one afternoon instead of a whole weekend or several days as is often common in Europe, thus increasing the accessibility of their larp style. Other forms of role-playing, such as jeepform, also involve one-room set-ups or guided narratives. Their combination with costumes and (non-representational) props ${ }^{18}$ usually associated with big outdoor larps in Europe, however, makes the Laymūn style particular and successful for its context. Laymūn have used this set-up effectively for their fantasy larps, letting players travel between locations, such as a tavern or the villain's castle, but this style shines with modern mystery and horror games. Fantasy adventures usually take place outside (imagine all the journeys and battles depicted in The Lord of the Rings). Thus, they require some level of suspension of disbelief when players fight orcs in an imagined, non-existing forest within the confines of a single room. Modern investigators of inexplicable phenomena need to strain their imagination less when playing inside. Using the available tables and chairs as well as other props, the half-rooms can function as a bar, someone's home, a library, or a corner in the woods. Players do not engage in big battles but if there are physical confrontations, for example with parents turned into zombies, the cramped room set-up adds to the atmosphere. Furthermore, the ability to switch off the lights to darken the room combined with sound effects makes sinister, brooding scenes in the darkness possible, where players have to use flashlights only to find gory body parts (see Figure 5). 


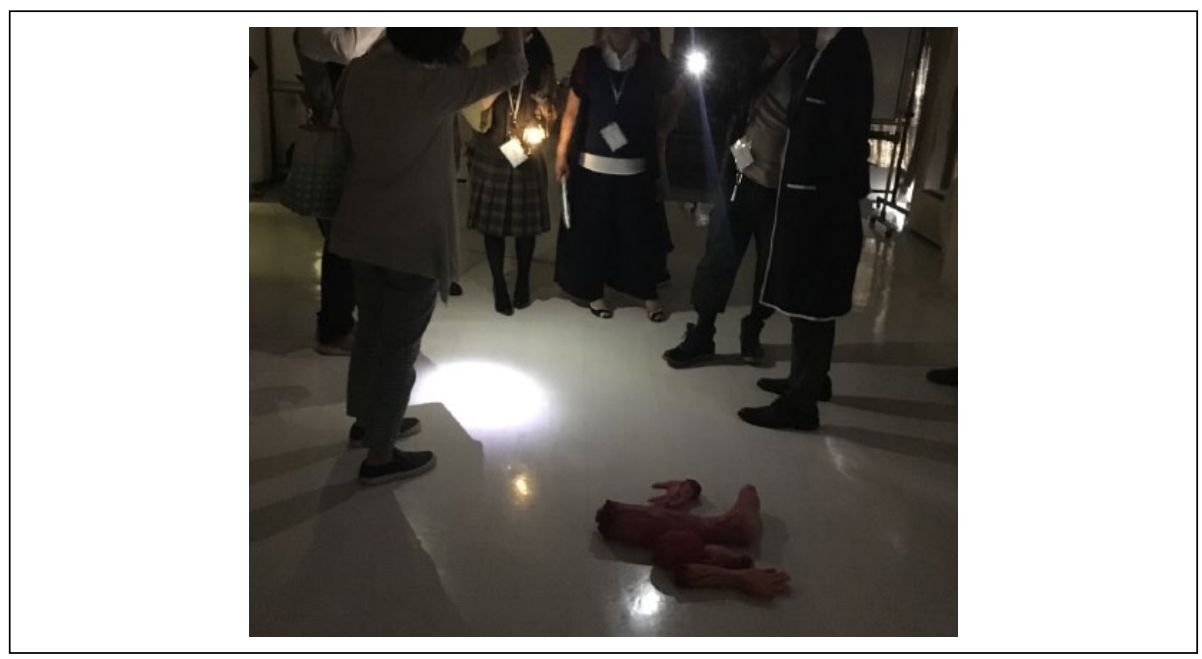

Figure5. Investigators and their grotesque findings (player faces removed for anonymity; photo provided by CLOSS, 2018).

Sword-and-sorcery and science-fiction necessitate a range of equipment, including armor, weapons or space suits. Modern horror allows players to participate in their everyday clothes instead. Thus, if you want to introduce new players to larp, not much preparation or investment is necessary on their part. Their costs are limited to 1.000-2.000 Yen participation fee for one day, during which players learn the rules and create characters in the morning, to then play those characters in the afternoon for 4-5 hours. ${ }^{19}$ Additionally, most newcomers have an easier time playing a student or novelist than a wizard or an orc shaman - regardless of prior experience with TRPGs, which most larpers (but not all) in Japan have. Many new-formed larp groups in Japan started playing Memento Mori after learning how to play in a CLOSS workshop before moving on to other genres.

Rule-wise, Memento Mori itself builds on elements people may know from $\mathrm{CoC}$ already, especially the sanity check. Keeping the tone of Lovecraft's stories, $\mathrm{CoC}$ in its various editions includes a sanity trait for its characters. When players encounter an ancient evil, are attacked by zombies, or read unholy scriptures, they have to succeed at a sanity check. If they fail, their characters suffer the consequences in the form of a reduced sanity score and temporary or permanent mental disorders. Similarly, in Memento Mori, strange encounters are divided into four categories, grotesque, mental, the five senses, and the unknown. Smelling burned flesh would fall under five senses, a talking skeleton would be a grotesque encounter. Depending on the kind of encounter, players have to succeed at drawing trump cards from the GM. Memento Mori in itself is not a $\mathrm{CoC}$ port to larp, so that players not necessarily face the King in Yellow, Deep Ones or other iconic entities from the Cthulhu Mythos. ${ }^{20}$ Judging from the play sessions I witnessed or participated in, the organizers rather borrow from the rich heritage of Japanese horror movies for such encounters and for emotional impact. 


\section{Emotional Impact}

A (player's) scream cuts through the sound of rain in the darkness when a flash light briefly illuminates a hunched, slender figure with long black hair covering its face. Everybody looks at the spot but the figure has disappeared as quickly as it blinked into existence. "I am actually scared now. . ." (Field notes, 2016).

This, of course, was an intertextual citation of Sadako, the ghostly antagonist of Suzuki Kōji's Ringu, best known through Nakata Hideo's film adaptation (1998). There are few who are not familiar, if not with the novel or film than at least with its iconic female ghost that kills everyone who happens to watch her cursed video tape. Ringu counts amongst Japan's most successful commercial films (McRoy, 2008). Sadako herself borrows from vengeful spirit tales of the 18th century and earlier as well as psychics of the early 20th century (Lacefield, 2010), however, so-called "J-Horror" movies like Ringu at the same time took also inspiration from British and US horror movies of the 1960s and 1970s (Brown, 2018). The above field note describes the first appearance of the familiar vengeful ghost figure in a Memento Mori scenario. The player characters suffer from various ghost and zombie attacks - with the monsters appearing one moment to only vanish in the next $\mathrm{t}^{21}$ - before they realize several inconsistencies about themselves and remember a fateful car crash at a forest shrine. To escape the Sadako-like spirit, they have to find clues on how to right a wrong they committed in the past but forgot.

Larps organized by Laymūn are structured into a couple of pre-plotted scene locations, such as scenes in the forest, at home, or in the library. The order of scenes, however, depends on player action and interaction, on when they find which clue and how they follow-up on it. The organizers may have to adjust details to integrate player choices but usually play-test their scenarios to such a degree, that they have scenes laid out for many player decisions. The scenarios do not railroad players to a particular ending: Their characters may die through a zombie attack or turn insane after learning a personal, dark secret. The whole group may fail when they do not deal with Sadako's "cousin" in due time (which is limited out-of-game to the opening hours of the community center where the larp takes place). Still, they may succeed in overcoming the ghost and their fear.

To create the atmosphere and draw players into their characters, the organizers create situations where player emotion and character emotion are in sync (cf. "bleed," Bowman, 2015). With their horror scenarios the Memento Mori designers seek to steer such moments to affect characters through their players. In a modern horror setting, player and character will most likely be familiar with Sadako and the legacy of vengeful spirits she represents. By using this familiar image in a brief moment of appearance and vanishing, (some) players react scared because they were scared when they watched Ringu. It does not matter if the player or the character remembers and utters in shock "I am scared now." In this instance they are one through the feeling - the personal memory of being scared - and its expression as the emotion of fear and an affective scream. ${ }^{22}$

Through distinguishing between player and character (cf. "alibi," Montola, 2010) but building on the affective-emotional connection of the two, larp allows participants 
to express feelings in a way they normally would not do. One can be fearful or heroic, confident or devout and explore these outlooks and emotional relationships within the sphere of the game. Simultaneously, the emotions experienced may be part of a fictional set-up and make-belief but are nonetheless real to the players, resulting in a lasting impact.

\section{Summary}

Horror larp focuses very much on such emotional impact and creating exciting, memorable experiences for participants. This has helped in drawing an increasing number of Japanese players to the practice in general, many of whom were already primed to the horror genre through niconico replay videos of Call of Cthulhu TRPGs. Furthermore, the way Laymūn actualize the practice by using spatial limitations and time restrictions in their favor, has provided interested players with tools and guidelines to easily realize their own games. Beginning with horror larps, many groups soon move on into the mainstream of fantasy. Still, in the realm of analog role-playing in Japan, the horror genre continues to be a central node point, a gatekeeper or better, a door-opener to interactively realizing stories through gaming. TRPGs and larps in Japan extend the family of role-playing game practices in particular ways through the addition of replays, a focus on horror, and the playstyle favored by Laymūn but are nonetheless connected to actualizations elsewhere.

\section{Declaration of Conflicting Interests}

The author declared no potential conflicts of interest with respect to the research, authorship, and/or publication of this article.

\section{Funding}

The author disclosed receipt of the following financial support for the research, authorship, and/ or publication of this article: The fieldwork in Japan between 2010 and 2014 was supported by fellowships from the German Institute for Japanese Studies, Tokyo (DIJ), and the FriedrichEbert-Foundation (FES).

\section{Notes}

1. This decade is known as "The Time of Winter" among older players, borrowing a phrase from Japanese socialists (fuyu no jidai). The slack period was overcome by this quicker and less time-consuming play style developed by some studios, e.g., F.E.AR., as well as recently the attention to the horror genre. Other game studios, such as GroupSNE, concentrated their endeavors on trading card games instead from the late 1990s, resuming their efforts in role-playing in the later 2000s.

2. A recent larp-rulebook includes a setting based on Japan's Warring States period (sengoku jidai, 1467-1600) and thus borrows heavily from movies and TV dramas classified as period pieces (jidaigeki). For example, villains are similarly depicted with disheveled hair and players speak a comparable mixture of modern Japanese intertwined with archaic sounding words (Hoshikuzu \& CLOSS, 2018). 
3. The English-language magazine created by Steve Jackson and Ian Livingstone focused on adventure gamebooks, where the reader can make choices and so create their own stories. The Japanese edition deviated from this focus and dealt more with TRPGs, especially when it continued until 1997 even though the English original had already ceased publication in 1986.

4. Which is now named RPG kenkyu-kai (RPG Study Club) and remains the oldest university club engaged in role-playing games.

5. Personal interview with Yasuda Hitoshi 2018.

6. A 30-year anniversary edition will be released in 2019, see https://sneakerbunko.jp/lodoss30th/ (accessed 2019/08/11).

7. Based on fiscal report by Kadokawa Inc., to which Dwango belongs since 2014. https://ssl4. eir-parts.net/doc/9468/ir_material_for_fiscal_ym1/51584/00.pdf (accessed 2019/08/11).

8. Live streams are available on the streaming platform Twitch. After airing, they are made available via YouTube, too. Cf. the series website https://www.critrole.com/ (accessed 2019/08/11). Few of my informants are familiar with English-language content. Only one stated to routinely look for information and games in English because he likes to gamemaster TRPGs not translated into Japanese to set himself apart from other players. Furthermore, the Japanese-language Internet is highly saturated, which - combined with a lack of (confidence in their) English capabilities - makes it unnecessary for players to consult English sources.

9. Worth mentioning, Lovecraft and Cthulhu have featured in or inspired various other works, including entities in the Hellboy comics and films or creatures in the Japanese television series Ultraman Tiga. Despite or due to his fame and influence, Lovecraft remains a controversial author because of his explicit racism. Many of his "others" and horrors out of space are symbols for his xenophobia, which is also discussed in Japanese scholarship on his literature (cf. Morise \& Kuro, 2018). Some of my informants are also aware of his racism. However, I have not observed play sessions of the CoC TRPG, so I cannot comment on how this is discussed at game tables. The replay videos I analyzed focus on gameplay.

10. The name-change from Kuturufu no yobigoe (literarily "Call of Cthulhu") to Kuturufu shinwa TRPG (Cthulhu Mythos TRPG) results from different license holders, Hobby Japan for the first translations, Enterbrain/Kadokawa for the current ones.

11. https://www.nicovideo.jp/watch/sm14018645 (accessed 2019/08/11).

12. Original light novel was written by Aisora Manta (2009); the anime was produced by studio Xebec and broadcast by TV Tokyo, TV Aichi, and TV Osaka from April-June 2012. A second season followed in 2013.

13. R'lyeh is a fictional, sunken city in the South Pacific in Lovecraft's work and Cthulhu's resting place.

14. CoC replays may also be filling the void of J-Horror movies (see below), after this genre lost creative steam in the mid-2000s despite being extremely popular on the domestic market and also abroad (Brown, 2018).

15. Live RPG refers to parallel, linked TRPG sessions at conventions where players move from one table to the next once they finished a task or challenge.

16. The US knows a long history of stereotypes linked to role-playing games, especially concerning occultism, where the magic in-game was believed to teach children demon-worship out-of-game. The Christian right in the US brought equal claims against Harry Potter in the 2000s (Laycock, 2015; Waldron, 2005). Japan never saw such heavy campaigning against TRPGs. There was only one TV broadcast in 1997 by journalist Egawa Shōko about the ill effects of role-playing and people fleeing into another world as it related to the Tokyo sarin-gas attacks by Aum Shinrikyō of 1995. According to my informants, some 
role-players appearing in this broadcast lost their jobs afterwards, however, because it was so difficult to explain what TRPGs were before being able to ridicule or criticize them, journalists did not follow-up on the practice. The case of a child-murderer in 1989, who was an anime video collector, on the other hand, created a negatively-charged atmosphere concerning fandom in Japan (cf. Galbraith, Kam, \& Kamm, 2015). This is what my informants referred to when they feared the public eye.

17. CLOSS and Laymūn use self-publishing platforms to distribute their rule- and guidebooks online, in game stores, or at events, such as the Comic Market or the Game Market. Contrastingly, GroupSNE's larp ruleset is available via "usual," mainstream outlets, such as Amazon or Rakuten.

18. "Non-representational" means that, for example, a realistically sized, plastic skull and other bones are used for the remains of a haunting ghost (and have to be returned to its resting place) or that an evil grimoire takes the form of an actual book bound in (artificial) leather and filled with pages upon pages of gibberish. "Representational" props would be cardboard cards on which the bones or the grimoire are depicted. The latter are common in US American "theater-style" larps.

19. Laymūn and the other larp circles I know only collect fees to cover their costs, such as room rental and travel expenses. CLOSS workshops may be a bit more expensive. Worldwide, amateur or semi-professionally run larps tend to barely cover the organizers' costs. Fully professional larps, where players pay around 700 EUR for three days and full lodging, remain a difficult business as the recent bankruptcy of the leading larp studio, Dziobak, in 2018 shows. Still, CLOSS seek to make their larp organizing and consulting into a business.

20. Because Memento Mori is an "all-purpose" rulebook, players are, of course, free to use its rules or adjust them for a more classic $\mathrm{CoC}$ game.

21. CLOSS have devised wound and make-up techniques, which allow for quick application and removal by the players of the monsters. Parents can thus quickly change into a zombielike appearance during a brief second in which the room is completely darkened.

22. Concerning feeling, emotion, and affect, see Shouse (2005).

\section{References}

Aisora, M. (2009). Haiyore! Nyaruko-san [Nyaruko: Crawling with love]. Tokyo, Japan: GA Bunko.

Appelcline, S. (2014). Designers \& dragons. A history of the roleplaying game industry-The 70 s. Silver Spring, MD: Evil Hat.

Apter, M. J. (1991). A structural-phenomenology of play. In M. J. Apter \& J. Kerr (Eds.), Adult play: A reversal theory approach (pp. 13-29). Amsterdam, The Netherlands: Swets \& Zeitlinger.

Bell, S. A. (2016). The $\mathrm{dB}$ in the .db: Vocaloid software as posthuman instrument. Popular Music and Society, 39(2), 222-240.

Bøckman, P. (2003). The three way model. Revision of the threefold model. In M. Gade, L. Thorup, \& M. Sander (Eds.), As larp grows up -Theory and methods in larp (pp. 12-16). Copenhagen, Denmark: BookPartner.

Bowman, S. L. (2010). The functions of role-playing games: How participants create community, solve problems and explore identity. Jefferson, NC: McFarland.

Bowman, S. L. (2015). Bleed: The spillover between player and character. Retrieved from https://nordiclarp.org/2015/03/02/bleed-the-spillover-between-player-and-character/ 
Brown, S. T. (2018). Japanese horror and the transnational cinema of sensations. Cham, Switzerland: Palgrave Macmillan.

CLOSS. (2018). JAPAN LARP GAMERS 2018. Tokyo, Japan: Popls.

Consalvo, M. (2016). Atari to Zelda: Japan's videogames in global contexts. Cambridge, MA: MIT Press.

Comiket. 2016. Comic Market 90 Catalogue. Tokyo: Comiket.

Fine, G. A. (1983). Shared fantasy: Role-playing games as social worlds. Chicago, IL: University of Chicago Press.

Galbraith, P. W., Kam, T. H., \& Kamm, B.-O. (Eds.). (2015). Debating otaku in contemporary Japan: Historical perspectives and new horizons. London, England: Bloomsbury Academic.

Griepp, M. (2016). Hobby games market nearly $\$ 1.2$ billion. Retrieved from https://icv2.com/ articles/news/view/35150/hobby-games-market-nearly-1-2-billion

Hammer, J., To, A., Schrier, K., Bowman, S. L., \& Kaufman, G. (2018). Learning and role-playing games. In J. P. Zagal \& S. Deterding (Eds.), Role-playing game studies: Transmedia foundations (pp. 283-299). New York, NY: Routledge.

Harviainen, J. T. (2012). Systemic perspectives on information in physically performed roleplay (Doctoral dissertation). University of Tampere, Finland.

Hinasaki, Y. (2013). LARP no Susume [LARP for you]. Kyoto, Japan: graphic.

Hinasaki, Y. (2015). LARP gèmu sākuru un'ei gaidobukku [LARP game circle management guidebook]. Tokyo, Japan: Popls.

Hinasaki, Y. (2019). Riaru RPG wo Nihon de yaritai!! LARP Funtōki [I want to play Real RPGs in Japan!! LARP Struggle Diary]. Tōkyō, Japan: Bōken.

Hine, C. (2008). Virtual ethnography: Modes, varieties, affordances. In N. Fielding, R. M. Lee, \& G. Blank (Eds.), Online research methods (pp. 257-270). London, England: SAGE.

Hitchens, M., \& Drachen, A. (2009). The many faces of role-playing games. International Journal of Role-Playing, 1(1), 3-21.

Ichiyanagi, H., \& Kume, Y. (Eds.). (2009). Raito noberu kenkyū josetsu [Introduction to light novel research]. Tōkyō, Japan: Seikyūsha.

Kamm, B.-O. (2011). Why Japan does not larp. In T. D. Henriksen, C. Bierlich, K. F. Hansen, \& V. Kølle (Eds.), Think larp. Academic writings from KP2011 (pp. 52-69). Copenhagen, Denmark: Rollespilsakademiet.

Kamm, B.-O. (2017). Brokers of "Japaneseness": Bringing table-top J-RPGs to the "West". Mutual Images Journal, 2, 44-81.

Kamm, B.-O. (2019). Adapting live-action role-play in Japan-How German 'Roots' do not destine Japanese 'Routes.' Replaying Japan, 1, 64-78.

Kamm, B.-O. (in press). Role-playing games of Japan: Transcultural dynamics and orderings. London, England: Palgrave Macmillan.

Katō, K., Fujino, H., Itoi, T., \& Yoneda, S. (2012). Kōinōjiheshõ supekutoramu ko no shōshūan ni okeru komyunikēshon-shien: Tēburu tōku rōrupureingu gēmu (TRPG) no yūkōsei nitsuite [Communication support for small groups of children with high function autism spectrum disorder: Effectiveness of a table-talk role playing game (TRPG)]. The Japanese Journal of Communication Disorders, 29(1), 9-17.

Katō, K., Fujino, H., \& Yoneda, S. (2013). Tēburutōku rōrupureingēmu katsudō ni okeru kōkinōjiheishō supekutoramu-ko no gōikeiseikatei [A process of "consensus making" in small groups of children with high functioning autism spectrum disorder, using a table-talk role-playing game]. The Japanese Journal of Communication Disorders, 30(3), 147-154. 
Kondō, K. (1987). Gēmu no dendō chinmi! Rōrupurei no gēmubukku-mushi (airurando-fu) wo meshiagare -"doragon-fantajī” shirīzu [Delicacies from the Palast of Games! Try role-play game-damped (Irish Style) - The "Dragon Fantasy" Series]. Warlock, 10, 31-32.

Lacefield, K.(Ed.). (2010). The scary screen: Media anxiety in The Ring. Farnham, UK: Ashgate. Laycock, J. P. (2015). Dangerous games. Oakland: University of California Press.

Lovecraft, H. P. (1928). The call of Cthulhu. Weird Tales, 11(2), 159-178.

Manimu. (2015). Jitsu ha meccha omoshiroi kuturufu shinwa TRPG [Actually really fun Cthulhu Mythos TRPG]. Retrieved from https://www.nicovideo.jp/watch/sm26000801

McRoy, J. (2008). Nightmare Japan: Contemporary Japanese horror cinema. Amsterdam, The Netherlands: Rodopi.

Montola, M. (2003). Role-playing as interactive construction of subjective diegeses. In M. Gade, L. Thorup, \& M. Sander (Eds.), As larp grows up: Theory and methods in larp (pp. 82-89). Copenhagen, Denmark: BookPartner.

Montola, M. (2010, August). The positive negative experience in extreme role-playing. Presented at the Nordic DiGRA 2010 Conference, Stockholm, Sweden. Retrieved from http://www.digra.org/wp-content/uploads/digital-library/10343.56524.pdf

Moreno, J. L. (1987). The essential Moreno: Writings on psychodrama, group method, and spontaneity. New York, NY: Springer.

Morise, R., \& Kuro, S. (2018). Kuturufu shinwa no atosaki [An account of the Cthulhu Mythos]. Eureka, 50, 38-53.

Morton, B. (2007). Larps and their cousins through the ages. In J. Donnis, M. Gade, \& L. Thorup (Eds.), Lifelike (pp. 245-259). Copenhagen, Denmark: BookPartner.

Nakamura, R. (2009). Raito noberu no ichigenryū - shippitsu sareru tēburutōku [One source of light novels - Writing table-talk]. In H. Ichiyanagi \& Y. Kume (Eds.), Raito noberu kenky $\bar{u}$ josetsu (pp. 104-118). Tōkyō, Japan: Seikyūsha.

Nakata, H. (1998). Ringu [film] [Japan]. Tokyo, Japan: Toho.

O’Donnell, C. (2012). The North American game industry. In P. Zackariasson \& T. L. Wilson (Eds.), The video game industry: Formation, present state, and future (pp. 99-115). New York, NY: Routledge.

Ogonoski, M. (2014). Cosplaying the media mix: Examining Japan's media environment, its static forms, and its influence on cosplay. Transformative Works and Cultures, 16. doi:10.3983/twc.2014.0526

Okawada, A. (2017). Sekai ni akerareta dankon to, tasogare no genkyō $\sim S F$ - gensō bungaku - gèmu ronsh $\bar{u}$ [The bullet that opened the world and the homeland of nostalgia - Essay collection on science fiction, fantasy, and games]. Tokyo, Japan: Atelier Third.

Ōtsuka, E. (2003). Kyarakutā-shōetsu no tsukurikata [How to write a character novel]. Tokyo, Japan: Kōdansha.

Peterson, J. (2012). Playing at the world: A history of simulating wars, people and fantastic adventures from chess to role-playing games (Kindle ed.). San Diego, CA: Unreal Press LLC.

Shouse, E. (2005). Feeling, emotion, affect. M/C Journal, 8(6). Retrieved from http://journal. media-culture.org.au/0512/03-shouse.php

Stenros, J., \& Montola, M. (2011). The making of Nordic Larp: Documenting a tradition of ephemeral co-creative play. In Proceedings of DiGRA 2011 Conference: Think Design Play, Utrecht School of the Arts, The Netherlands, September. 
Teli, M., Pisanu, F., \& Hakken, D. (2007). The Internet as a library-of-people: For a cyberethnography of online groups. Forum: Qualitative Social Research, 8(3). doi:10.17169/ fqs-8.3.283

Uchiyama, Y. (2009). Ruruie antiku: kuturufu shinwa TRPG ripurei [R'lyeh Antique: Call of Cthulhu TRPG Replay]. Tokyo, Japan: Enterbrain.

Waldron, D. (2005). Role-playing games and the Christian right: Community formation in response to a moral panic. Journal of Religion and Popular Culture, 9(1), 3. doi:10.3138/ jrpc.9.1.003

Winge, T. (2006). Costuming the imagination: Origins of anime and manga cosplay. Mechademia, 1(1), 65-76.

Winkler, W. K. (2006). The Business and the culture of gaming. In J. P. Williams, S. Q. Hendricks, \& W. K. Winkler (Eds.), Gaming as culture: Essays on reality, identity and experience in fantasy games (pp. 140-153). Jefferson, NC: McFarland.

Wittgenstein, L. (2009). Philosophical investigations (G. E. M. Anscombe, P. M. S. Hacker, \& J. Schulte, Trans., 3rd ed.). Malden, MA: Blackwell. (Original work published 1953)

Yasuda, H., \& GroupSNE. (1986, September). D\&D Rōdosu-tō senki replay dai 1 bu [D\&D Record of Lodoss War Replay, Part 1] (In Comtiq). Tokyo, Japan: Kadokawa.

Yasuda, R. (2016). TRPG no rekishi, tokuchō karajicchi de no katsuyō nitsuite [On the practical use of TRPG from their history and features]. Yügi-shi kenkyū, 28, 44-60.

Young, M. J. (2003, June 30). Applied theory. Retrieved from http://www.indie-rpgs.com/articles $/ 23 /$

Zagal, J. P., \& Deterding, S. (Eds.). (2018). Role-playing game studies: Transmedia foundations. New York, NY: Routledge.

\section{Ludography}

Dziobak. (2015). Fairweather Manor [Larp]. Available from https://www.fmlarp.com

Greenberg, A. C., \& Woodhead, R. (1981). Wizardry (1st ed.) [video game] [Apple II]. New York, NY: Sir-Tech.

Gygax, G., \& Arneson, D. (1974). Dungeons \& Dragons (1st ed.) [Role-playing game book]. Lake Geneva, WI: TSR Inc.

Gygax, G., Arneson, D., Tweet, J., Cook, M., \& Williams, S. (2003). Dungeons \& Dragons core rulebook I: Player's handbook (3.5th ed.) [Role-playing game book]. Renton, WA: Wizards of the Coast.

Horii, Y. (1986). Dragon Quest (1st ed.) [video game] [Famicom/NES]. Tokyo, Japan: Enix.

Hoshikuzu, \& CLOSS. (2015). Kan'i han'yō horā LARP gēmu Memento Mori [Simple \& general horror LARP game memento mori] [Larp game book]. Tokyo, Japan: Popls.

Hoshikuzu, \& CLOSS. (2018). Japonés Fantasy LARP Gekka Sakuran [Larp game book]. Tokyo, Japan: Popls.

Kitazawa, K., \& GroupSNE. (2018). Sōdo Wārudo 2.5 [Sword World 2.5] [Role-playing game book]. Tokyo, Japan: Fujimi Shobō.

Live Adventure. (2004). ConQuest of Mythodea [Larp]. Available from http://www.live-adventure.de/

Miller, M., Chadwick, F., Harshman, J. \& Wiseman, L. (1977). Traveller (1st ed.) [Role-playing game book]. Normal: Game Designer's Workshop.

Ohlen, J. (1998). Baldur's Gate (1st ed.) [video game] [MS Windows/Mac OS]. Edmonton, Alberta, Canada: BioWare. 
Okada, A. (2007). Ryūtama: Natural fantasy R.P.G. [Role-playing game book]. Tokyo, Japan: Jaibu.

Okada, A. (2015). Ryuutama: Natural fantasy role-playing game [Role-playing game book] (A. Kitkowski \& M. Sanchez, Trans.). Research Triangle Park, NC: Kotodama Heavy Industries.

Petersen, S., \& Willis, L. (1981). Call of Cthulhu (1st ed.) [Role-playing game book]. Oakland, CA: Chaosium.

Petersen, S., \& Willis, L. (1986). Kuturufu no yobigoe [Call of Cthulhu] [Role-playing game book] (J. Arisaka, Trans.). Tokyo, Japan: Hobby Japan.

Petersen, S., \& Willis, L. (2004). Kuturufu shinwa TRPG [Cthulhu Mythos TRPG] [Roleplaying game book] (T. Nakayama \& M. Sakamoto, Trans.). Tokyo, Japan: Kadokawa.

Petersen, S., Willis, L., Mason, M., \& Fricker, P. (2016). Call of Cthulhu. Ann Arbor, MI: Chaosium.

Rein Hagen, M. (1991). Vampire: The masquerade (1st ed.) [Role-playing game book]. Stone Mountain, Georgia: White Wolf.

Sakaguchi, H. (1987). Final fantasy (1st ed.) [video game] [Famicom/NES]. Tokyo, Japan: Square.

Sakamoto, M., \& Bandō, S. (2005). Kuturufu to teikoku [Cthulhu and Empire] [Role-playing game book]. Tokyo, Japan: Kadokawa.

Sakamoto, M., Uchiyama, Y., \& Bandō, S. (2010). Kuturufu 2010 [Cthulhu 2010] [Role-playing game book]. Tokyo, Japan: Kadokawa.

Sakamoto, M., Uchiyama, Y., \& Bandō, S. (2015). Kuturufu 2015 [Cthulhu 2015] [Role-playing game book]. Tokyo, Japan: Kadokawa.

Schlump, F., \& Hölzel, B. (2004). DragonSys (2nd ed.) [Larp game book]. Zirndorf, Germany: $\mathrm{G}$ und $\mathrm{S}$.

Stahlberg, N., \& Sugiura, N. (2012). Patoria Sōrisu [Larp game book]. Tokyo, Japan: Selfpublished.

\section{Author Biography}

Björn-Ole Kamm is a senior lecturer at the Graduate School of Letters, Kyoto University, and coordinates a joint degree master program in Transcultural Studies with Heidelberg University. His research engages the various forms of non-digital role-playing, especially concerning questions of how practices are locally adapted and transformed. He furthermore explores larp as a method to make qualitative social-science research results experienceable (edu-larp, transcultural learning).

Contact: kamm.bjornole.7e@kyoto-u.ac.jp 